\title{
The Effectiveness of Proper Oleation Features of Instant and Incremental Oleation on Serum Sodium and Potassium in Healthy Volunteers - A Pilot Study
}

\author{
Punam Sawarkar ${ }^{1,2, *}$ and Gaurav Sawarkar ${ }^{1,2}$ \\ 'Mahatma Gandhi Ayurved College, Hospital and Research Centre, Salod (H), Wardha, \\ Maharashtra, India \\ 2Datta Meghe Institute of Medical Sciences (Deemed to be University), Sawangi \\ (Meghe), Wardha, Maharashtra, India
}

\begin{abstract}
Article Type: Article
Article Citation: Farhad

Hekmatipour, Milad Jalali. The

effectiveness of proper oleation features

of instant and incremental oleation on

serum sodium and potassium in healthy

volunteers - a pilot study. Indian

Journal of Science and Technology.

2020; 13(05), 487-492. DOl: 10.17485/

ijst/2020/v013i05/148085
\end{abstract}

Received date: 0 ctober 10, 2019

Accepted date: January 22, 2020

*Author for correspondence:

Punam Sawarkar \drsuple.punam@ gmail.com 9 Mahatma Gandhi Ayurved College, Hospital and Research Centre, Salod (H), Wardha, Maharashtra, India

\begin{abstract}
Introduction: Panchakarma itself is a composite and distinctive system of treatment, so its pharmaceutical preparations also possess some special characteristics. Oleation is the essential prerequisite for purification i.e. putative therapy which is indicated in physiological as well as pathological conditions. Generally, incremental oleation is indicated to achieve and make a good platform for excitation of toxins. But this type of regime is quiet time consuming and costly as compared to instant oleation. Objective: The present study is aimed to ascertain and compare the efficacy of instant oleation in healthy volunteers on certain subjective and objective parameters with that of traditional incremental oleation. Methods: Total 30 participants divided into two groups; group A with instant oleation (plain cow ghee and rock salt) and group B (only plain cow ghee). Blood analysis for serum sodium and serum potassium was done before and after the oleation. And certain subjective parameters were also assessed before and after the oleation in both the groups. Results: Serum sodium and serum potassium were found statistically nonsignificant $(p<0.05)$, while all other subjective parameters were improved ( $p<0.001)$ except aversion to fat and loose consistency of stool. Conclusion: In both the oleation methods i.e. instant and incremental oleation, all subjective criteria improved significantly ( $p<0.001$ and $p<0.01$ ), except aversion to the fat and loose consistency of stool. Though, loose consistency quite improved in group 2. The assessment of objective criteria i.e. serum sodium and serum potassium found to be statistically non-significant $(p<0.05)$ before, after of unction and between the groups; deficit of sample size may be the reason behind the outcome.
\end{abstract}

Keywords: Panchakarma, Purification, Oleation, Unction. 


\section{Introduction}

Oleation (Snehapana) is one of the pre-procedure therapies in Panchakarma. Fat either Oil or Ghee, oleation is a prerequisite in Panchakarma procedure [1]. The ghee is made of clarified butter (obtained from cow's milk) and it is boiled with various herbs to make a specific disease-oriented medicine. Oleation is process of intake of fat in specified dose for stipulated duration. The entire procedure of elimination of toxins (Śhodhana) depends upon the proper mobilization of humors (Doshas) from the extremities to the gastrointestinal tract [2]. This is to be achieved with the help of oleation which brings liquefaction of humors for their migration. The treatment lasts between five and seven days depending on the condition of the patient and the illness being treated [3]. The fat with its qualities of liquefying the humors segregated in the tissues and migrates to gastrointestinal tract and other abdominal organs and its corresponding circulations. At the time of migration, various changes have been occurring in the body. One of the factors in terms of serum sodium (Sr.Na) \& serum potassium (Sr.K) in phasic manner of migration was deliberate in this present pilot study. So, the present study intended for evaluation of proper oleation effect of instant and incremental oleation on serum sodium and serum potassium in healthy volunteers.

\section{Material \& Method}

Selection of material: Cow ghee and rock salt, was procured from local authenticated reliable sources.

Toxicity studies: No such type of study observed though cow ghee and rock salt are edible.

Sample size: 30 subjects ( 15 for each group)

Sample selection techniques: Randomization (Closed envelop method)

Groups: 2 groups

Group A: Instant oleation (Plain Cow Ghee + Rock salt)

Group B: Incremental oleation (Plain Cow Ghee)

Study design: Double arm study (Table 1)

Study type: Interventional

Inclusion criteria: Healthy volunteers irrespective of sex having age between 18 and 48 years indicated for oleation [4] as well as purification procedure were included in the study.

Exclusion criterion: Known subjects of renal or hepatic impairment, any medical or surgical illness, pregnant and lactating women, having aversion to fat consumption were excluded from the study.

\section{Observation and Results}

In both the groups, all symptoms improved significantly after treatment. There was significant difference observed between both groups except aversion to fat and loose 
TABLE 1. Posology in details

\begin{tabular}{|c|c|c|}
\hline Group & Group A & Group B \\
\hline Sample size & 15 samples & 15 samples \\
\hline $\begin{array}{l}\text { Pre interventional } \\
\text { procedure }\end{array}$ & \multicolumn{2}{|c|}{$\begin{array}{l}\text { Appetizer Trikatu powder(Zingiberofficinale, Piper nigrum, Piper } \\
\text { longum) with } 3 \text { grams before meal twice daily with lukewarm water for } \\
\text { consecutive } 3 \text { days }\end{array}$} \\
\hline $\begin{array}{l}\text { First blood sample } \\
\text { collection }\end{array}$ & \multicolumn{2}{|c|}{ On fourth day morning (empty stomach) } \\
\hline Intervention & $\begin{array}{l}\text { On fifth day morning around } 7 \\
\text { a.m .Instant Oleation with } 150 \\
\text { grams cow ghee }+10 \mathrm{~g} \text { Rock Salt }\end{array}$ & $\begin{array}{l}\text { Start incremental snehana from fifth } \\
\text { day onwards around } 7 \text { a.m. with cow } \\
\text { ghee }\end{array}$ \\
\hline Dose & $\begin{array}{l}150 \text { g cow ghee }+10 \text { g rack saltin } \\
\text { one day }\end{array}$ & $\begin{array}{l}24,48,72,96,120,144 \text {, and } 168 \mathrm{~g} \\
\text { consecutively incremental dose for } \\
3 / 5 / 7 \text { days as per needed till the } \\
\text { appearance of proper oleation effect }\end{array}$ \\
\hline $\begin{array}{l}\text { Duration of } \\
\text { intervention }\end{array}$ & 1 day & $3 / 5 / 7$ days \\
\hline $\begin{array}{l}\text { Second blood sample } \\
\text { collection }\end{array}$ & $\begin{array}{l}\text { On sixth day morning (empty } \\
\text { stomach) }\end{array}$ & $\begin{array}{l}\text { After } 24 \text { hours of consumption } \\
\text { of last dose of cow ghee (empty } \\
\text { stomach) }\end{array}$ \\
\hline Total duration & 4 days & 10 days \\
\hline
\end{tabular}

consistency of stool. But, in group B loose consistency of stool was quite improved after unction (Table 2).

The changes that occurred with the unction are not great enough to exclude the possibility that the difference is due to chance (Tables 3 and 4).

TABLE 2. Statistical observations of subjective criteria before and after unction

\begin{tabular}{|c|c|c|c|c|}
\hline \multirow[b]{2}{*}{ Symptoms } & \multicolumn{2}{|c|}{ Group A } & \multicolumn{2}{|c|}{ Group B } \\
\hline & $\begin{array}{l}\text { Before } \\
\text { unction }\end{array}$ & After unction & $\begin{array}{l}\text { Before } \\
\text { unction }\end{array}$ & After unction \\
\hline $\begin{array}{l}\text { Capacity to intake of meal } \\
\text { (Abhyavaharana Shakti) }\end{array}$ & $3(1-6)$ & $4(2-6)^{* * *}$ & $4(1-6)^{@}$ & $5(2-6) * * * @ @$ \\
\hline $\begin{array}{l}\text { Improvement in digestive } \\
\text { energy(Agni dipti) }\end{array}$ & $2(1-6)$ & $3(2-6)^{* * *}$ & $4(1-6)^{@}$ & $5(2-6)^{* * * @ @ ~}$ \\
\hline General lassitude(Klama) & $2(1-5)$ & $3(1-5)^{* * *}$ & $2(1-5)$ & $3.5(1-6) * * * @ @$ \\
\hline Aversion to fat (Snehodwega) & $1(1-3)$ & $2(1-4)^{* * *}$ & $1(1-4)$ & $0(3-5)^{* * *}$ \\
\hline $\begin{array}{l}\text { Skin oiliness (Twak } \\
\text { Snigdhata) }\end{array}$ & $2(1-5)$ & $4(1-6)^{* * *}$ & $2(1-6)$ & $5(1-6) * * * @$ \\
\hline $\begin{array}{l}\text { Skin softness (Gatra } \\
\text { Mardava) }\end{array}$ & $2(1-3)$ & $3(2-5)^{* * *}$ & $2(1-3)$ & $3(1-4) * * * @$ \\
\hline $\begin{array}{l}\text { Loose consistency of stool } \\
\text { (Mala Asamhati) }\end{array}$ & $2(1-5)$ & $2(2-7)^{* * *}$ & $1(1-6)$ & $3(1-7)^{\star * *}$ \\
\hline $\begin{array}{l}\text { Stool oiliness (Purisha } \\
\text { Snigdhata) }\end{array}$ & $2(1-4)$ & $3(2-5)^{* * *}$ & $2(1-4)$ & $3(1-5) * * * @$ \\
\hline $\begin{array}{l}\text { Easy evacuation of flatus } \\
\text { (Vatanulomana) }\end{array}$ & $2(1-5)$ & $3(1-5)^{* * *}$ & $3(1-5)$ & $4(2-5) * * * @$ \\
\hline
\end{tabular}

${ }^{* * *} p<0.001$ using Wilcoxon matched-pairs signed-ranks test as compared to before unction.

${ }^{\circledR} p<0.05$, ${ }^{@} p<0.01$ using Mann-Whitney Test as compared to Group A. 
The Effectiveness of Proper Oleation Features of Instant and Incremental Oleation on Serum Sodium and Potassium in Healthy Volunteers - A Pilot Study

TABLE 3. Comparison of Sr. Na \& Sr. K before and after unction within incremental oleation group

\begin{tabular}{llllllll}
\hline Parameter & Treatment name & $\boldsymbol{N}$ & Mean & Std dev & SEM & T value & $\boldsymbol{P}$ value \\
\hline \multirow{2}{*}{ Sr. Na } & Before & 15 & 139.533 & 2.031 & 0.524 & & \\
& After & 15 & 140.8 & 2.513 & 0.649 & & 0.100 \\
\multirow{2}{*}{ Sr. K } & Before & 15 & 4.14 & 0.25 & 0.0646 & \multirow{2}{*}{1.153} & 0.150 \\
& After & 15 & 3.973 & 0.369 & 0.0954 & & \\
\hline
\end{tabular}

TABLE 4. Comparison of Sr. Na \& Sr. K before and after unction within instant oleation group

\begin{tabular}{llllllll}
\hline Parameter & Treatment name & $\boldsymbol{N}$ & Mean & Std dev & SEM & $\boldsymbol{T}$ value & $\boldsymbol{P}$ value \\
\hline \multirow{2}{*}{ Sr. Na } & Before & 15 & 139.533 & 2.924 & 0.755 & & \\
& After & 15 & 139 & 3.185 & 0.822 & 1.054 & 0.310 \\
\multirow{2}{*}{ Sr. K } & Before & 15 & 4.159 & 0.408 & 0.105 & -0.136 & 0.894 \\
& After & 15 & 4.173 & 0.363 & 0.0938 & & \\
\hline
\end{tabular}

The difference in the mean and median values of the two groups is not great enough to reject the possibility that the difference is due to random sampling variability. There is not a statistically significant difference between the input groups (Tables 5 and 6).

TABLE 5. Comparison of before oleation Sr. Na \& Sr. K in between both the groups

\begin{tabular}{llllllll}
\hline Parameter & Group & $\boldsymbol{N}$ & Mean & Std dev & SEM & T value & P value \\
\hline \multirow{2}{*}{ Sr. Na } & A & 15 & 139.533 & 2.924 & 0.755 & 0.000 & \multirow{2}{*}{1.000} \\
& B & 15 & 139.533 & 2.031 & 0.524 & & \\
& & & Median & $\mathbf{2 5 \%}$ & $\mathbf{7 5 \%}$ & & \\
Sr. K & A & 15 & 4.03 & 3.925 & 4.35 & 219.500 & 0.360 \\
& B & 15 & 4.2 & 4 & 4.2 & & \\
\hline
\end{tabular}

TABLE 6. Comparison of after oleation Sr. Na \& Sr. K in between both the groups

\begin{tabular}{llllllll}
\hline Parameter & Group & $\boldsymbol{N}$ & Mean & Std dev & SEM & $\boldsymbol{T}$ value & $\boldsymbol{P}$ value \\
\hline \multirow{2}{*}{ Sr. Na } & A & 15 & 139 & 3.185 & 0.822 & & \\
& B & 15 & 140.8 & 2.513 & 0.649 & & 0.097 \\
\multirow{2}{*}{ Sr. K } & A & 15 & 4.173 & 0.363 & 0.0938 & 1.495 & 0.146 \\
& B & 15 & 3.973 & 0.369 & 0.0954 & & \\
\hline
\end{tabular}

\section{Discussion}

The capacity to intake of meal increased and digestive energy improved statistically in both the groups. Pure ghee contains no hydrogenated oil which is associated with weight 
gain as its lower metabolism but also interferes with bodily ability to ingest and utilize the good fat causing to eat more in order to feel full. Little TJ reported that the physiological mechanisms that sense the presence of fat in both the oral cavity and the small intestine, and high-fat diet exposure that may modulate digestion and thereby contribute to the regulation of appetite [5].

Instant and incremental unction showed significant change in general lassitude that was because of fat intake. Well AS also stated regarding the influence of fat that there is an association between the lassitude experienced after a fatty meal and the release of CCK [6].

Excessive fat intake may create aversion to fat that person not ready to eat a single drop of ghee after some extent of time. Andrew et al. also convey the same thing about fat taste that free fatty acids (FFAs) activate fat taste receptors located on taste cells and human lingual lipases also increase FFA exposure in the oral cavity by hydrolysing triacylglycerides (TAGs). In large amounts, FFAs elicit a fetid taste to prevent the consumption of more lipids in foods. But, in present study changes was not found statistically significant [7].

Proper oleation symptoms as described in Ayurveda context appear in a sequential manner, however, some symptoms such as softness and oiliness of skin are difficult to achieve and may not appear in all participants. But, in this study statistical improvement was found in case of softness and oiliness of skin [3].

After high fat consumption loose consistency of stool was observed due to bile acid malabsorption Dietary Lipids and Functional Gastrointestinal Disorders [8]. Stool oiliness may feel by participants due to high fat intake and in case of impaired fat absorption Walker B.E. was stated that participants seemed likely to have mild or borderline steatorrhea in this type of participants who poses the most difficulty in deciding the presence or absence oiliness in stool [11].

In the present study, it was found that oleation facilitated easy evacuation of flatus. But previous observations informed that dairy products are one of the causes of formation gas that impaired the digestive function of the person [10]. Unction with rock salt oleates the body instantaneously because by nature it obstructs the channel of circulation, unctuous that passes though subtle channels, which gets digested only after its absorption and pervasion in the whole body [11].

In [12] both the groups, all symptoms improved significantly after treatment. There was significant difference observed between both groups except aversion to fat and loose consistency of the stool due to the variability in individual tolerance level. But, in group B loose consistency of stool was quite improved after unction in view of statistical analysis, the before and after observations of serum sodium and potassium was not significant and the changes may occur due to chance. The changes in serum sodium and potassium in between both groups not so enough and statistically not significant, there was a possibility that the difference is due to random sampling variability. Statistically not significant results may suggest that sample size was too small to conclude the expected results in the study.

\section{Conclusion}

In both the oleation methods i.e. instant and incremental unction, all subjective criteria improved significantly $(p<0.001$ and $p<0.01)$, except aversion to the fat and loose 
consistency of stool. Though, loose consistency quite improved in group 2 . The assessment of objective criteria i.e. serum sodium and serum potassium found to be statistically nonsignificant $(p<0.05)$ before, after of unction and between the groups; deficit of sample size may be the reason behind the outcome.

\section{Recommendation}

In the present study, analysis of subjective parameters was satisfactory. But, because of less sample size the statistical results of objective criteria were found non-significant. So, similar research study is recommended with more sample size by other hematological and biochemical objective parameters.

\section{References}

1. Sharma P, Samhita C. Sutrasthana. Chaukhamba Orientalia, Varansi. 2007; 90. http://niimh.nic. in/ebooks/ecaraka/?mod=adhi

2. Trikamji Y, Samhita C, Sutrastana Chapter 13/24. Rastriya Samskrit Samsasthan. New Delhi. 2006; 89. http://niimh.nic.in/ebooks/ecaraka/?mod=adhi

3. Patil VC, Thakar AB, Baghel MS. Clinical trial on different dose patterns of Shodhanartha Abhyantara Snehana. Ayu. 2013; 34(2), 147-153. DOI: 10.4103/0974-8520.119668.

4. Trikamji Y, Samhita C. Sutrastana chapter 13/52, Rastriya Samskrit Samsasthan. New Delhi. 2006; 112. http://niimh.nic.in/ebooks/ecaraka/?mod=adhi

5. Little TJ, Feinle-Bisset C. Effects of dietary fat on appetite and energy intake in health and obesity--oral and gastrointestinal sensory contributions. Physiology \& Behavior. 2011; 104(4), 613-620. DOI: 10.1016/j.physbeh.2011.04.03.

6. Wells AS1, Read NW, Uvnas-Moberg K, Alster P, Influences of fat and carbohydrate on postprandial sleepiness, mood, and hormones. Physiology \& Behavior. 1997; 61(5), 679-686. DOI: 10.1016/s0031-9384(96)00519-7.

7. Costanzo A. Fat taste sensitivity is associated with short-term and habitual fat intake. Nutrients. 2017; 9, 781. DOI: 10.3390/nu9070781.

8. Vasant P. Snehana therapy in Ayurveda. 1st edn. Chaukhamabha Publications: New Delhi. 2008; 150 .

9. Feinle-Bisset C, Azpiroz F. Dietary lipids and functional gastrointestinal disorders. The American Journal of Gastroenterology. 2013; 108(5), 737-747. DOI: 10.1038/ajg.2013.76.

10. Walker BE. Influence of dietary fat on fecal fat. Gastroenterology. 1973; 64(2), 233-239. https:// www.ncbi.nlm.nih.gov/pubmed/4686332

11. Clinic M. Ways to reduce gassiness: certain foods may cause gas. ScienceDaily. 2008. https:// www.sciencedaily.com/releases/2008/01/080104123911.htm

12. Trikamji Y, Samhita C. Sutrastana chapter 13/98. Rastriya Samskrit Samsasthan. New Delhi, 2006; 94. http://niimh.nic.in/ebooks/ecaraka/?mod=adhi 